\title{
Groundwater contamination in Agbowo community, Ibadan Nigeria: Impact of septic tanks distances to wells
}

\author{
Victoria Olusola Adetunji ${ }^{\star}$, and Ismail Ayoade Odetokun \\ Department of Veterinary Public Health and Preventive Medicine, University of Ibadan, Ibadan, Nigeria. \\ E-mail: vadetunji@gmail.com; vo.adetunji@mail.ui.edu.ng
}

Received 7 June 2011; received in revised form 5 July 2011; accepted 20 July 2011

\begin{abstract}
In Nigeria, inadequate supply of pipe borne water is a major concern; hence many homes have wells as a source of water for household uses. The groundwater of forty wells in Agbowo community was assessed for Total Aerobic Bacteria Counts (TABC) and Total Coliform Counts (TCC). The location and distances of wells from septic tanks were determined using the Global Positioning System (GPS) device and a tape rule respectively. All the wells sampled had high TABC $(4.76 \pm 1.41 \log C F U / \mathrm{mL})$ and TCC $(2.29 \pm 0.67 \log C F U / \mathrm{mL})$ counts which exceeded the international standard of 0 per $100 \mathrm{~mL}$ of potable water. There were no significant differences in the bacterial counts between covered and uncovered wells $(p>0.05)$. The mean distance $(8.93 \pm 3.61 \mathrm{~m})$ of wells from the septic tanks was below the limit $(15.24 \mathrm{~m}$ or $50 \mathrm{ft}) \mathrm{set}$ by United State Environmental Protection Agency (USEPA). TABC increased with a decrease in distance between the wells and septic tanks though not significant $(p<0.05)$. A very weak positive correlation $\left(r^{2}=0.021\right)$ ensued between the distance from septic tank and CC, while a weak negative correlation $\left(r^{2}=-0.261\right)$ was obtained between the TCC and TABC. This study accentuates the need to set standards for the siting of wells from septic tanks while considering all possible sources of well contamination as well as treatment of ground water before use.
\end{abstract}

Keywords: Groundwater, wells, septic tanks, coliform count, total aerobic bacteria count

\section{INTRODUCTION}

As population grows and urbanization increases, more water is required and greater demand is made on ground and surface water. The rate of urbanization in Nigeria is alarming and the major cities areas are growing at rates between 10-15\% per annum (Yusuf, 2007) and thus, human activities including soil fertility remediation, indiscriminate refuse and waste disposal, and the use of septic tanks, soak-away pits and pit latrines are on the increase. Groundwater pollution has been attributed to the process of industrialization and urbanization that has progressively developed over time without any regard for environmental consequences (Longe and Balogun, 2010) which eventually results in the deterioration of physical, chemical and biological properties of water (Isikwe et al., 2011).

In Nigeria, there is the challenge of lack of supply of pipe borne water hence many homes have wells sited around the house at a distance from the septic tank. 52\% of Nigerians do not have access to improved drinking water supply (Orebiyi et al., 2010). For most communities the most secure source of safe drinking water is pipeborne water from municipal water treatment plants. Often, most of water treatment facilities do not deliver or fail to meet the water requirements of the served community; due to corruption, lack of maintenance or increased population. The scarcity of piped water has made communities to find alternative sources of water: ground water sources being a ready source. Wells are a common ground water source readily explored to meet community water requirement or make up the short fall (Adekunle, 2008). This is the situation in many parts of Nigeria and several other African countries (Adelekan, 2010). These wells serve as major source of water for household uses (drinking, cooking, washing etc.). Commonest cause of pollution is attributed to close proximity of septic tanks to wells, unhygienic usage of the wells e.g. some wells have no cover/lids; they are dirty and unkempt thus, making the water unfit for use, resulting into water borne diseases. Groundwater pollution may also be caused by the disposal of solid or liquid wastes in pits, abandoned boreholes or even stream channels and landfills (Onunkwo and Uzoije, 2011). Safe drinking water remains inaccessible for about 1.1 billion people in the world (Mintz et al., 2001). Those most susceptible to water borne illnesses are children, the elderly, pregnant women and immunocompromised individuals, making water-borne illnesses one of the five leading causes of death among children under age five (Gerba et al., 1996). In 1997, the World Health Organization (W.H.O.) reported that $40 \%$ of deaths in developing nations occur due to infections from water related diseases and an estimated 500 million cases of diarrhea, occurs every year in children below 5 years in parts of Asia, Africa and Latin America (Adejuwon and Mbuk, 2011). 
Ibadan suffers serious water supply problems; cases of dry taps are common in virtually every part of the city. Sights of children/women searching for water are common experience (Ifabiyi, 2008). Potable water is one that does not contain chemical substances or microorganisms in amount that can cause hazards to health (Alonge, 2005). Water must be substantially free of dissolved salts, plant, animal waste and bacterial contamination to be suitable for human consumption. Poorly designed septic tanks and inadequately maintained septic systems have contaminated ground water with nitrates, bacteria and toxic cleaning agents. This can serve as a vehicle for spreading illnesses caused by such microorganisms as Vibrio cholera, Yersinia enterocolitica, Escherichia coli, Cryptosporidium spp. and vector borne diseases such as guinea worm, schistosomiasis, lymphatic filariosis, onchocerciasis, parasitic and viral infections (Swerdlow et al., 1992; Mackenzie et al., 1995). Feacal (Simango et al., 1992; Obi et al., 2002; Fenwick, 2006) and chemical (from industries and farms) contamination, combined with the failure to adequately treat water, have been incriminated in many water borne epidemics (CDC, 1993; Bridgman et al., 1995). The risk of contaminated water for people was manifested in Lake Erie, Ohio, USA in 2004 when 1450 people became ill because of a pathogen in the well water (Fong et al., 2007). Microbial feacal contamination indicators are Echerichia coli, Clostridia spp., Streptococci (Binnie et al., 2002; Simpson et al., 2002; Scott et al., 2002) and other bacteria that could be of human or non-human origin. Escherichia coli, particularly those possessing virulence markers as; haemolysin, verocytotoxin and belonging to the enteropathogenic serotypes have been responsible for gastroenteritis in humans (Griffin and Tauxe, 1991; Bell et al., 1994; NRC, 1998). Hence, the need to ensure the supply of potable water is a priority to prevention of water borne illnesses. The increasing dependence on ground water as a source of potable water has spurred efforts to protect the quality of this limited resource.

It has been estimated that the total volume of waste disposed off via septic tanks is approximately 800 million gallon per year, virtually all of which is disposed in the subsurface (USEPA, 1977). This makes septic tanks the leading contributor to the total volume of waste discharged directly to ground water. Assessment of water is therefore very crucial to safeguard public health and the environment (Lin et al., 2010). Climatic conditions, land use patterns, vegetative cover, topography, soil and geologic characteristics, well condition, location of potential pollution sources, and agricultural management practices can affect the transport and contamination of groundwater by bacteria (Bourne, 2001). Various factors affect the microbiological quality of groundwater. In areas where the depth to bedrock is shallow, there is little interaction with the soil and, therefore, contaminants are not effectively removed (Conboy and Goss, 2000).

It is noteworthy that Individual houses in Agbowo, Ibadan, are closely parked together in an in orderly fashion with high number of inhabitants. Refuse dumps, pit latrines and open sewers are common. Environmental sanitation is almost nil. All these suggest possible chances of pollutants and contaminants entering these wells. Improving the quality of groundwater resources offers an important economic opportunity for the gradual improvement of the quality of life (Valenzuela et al., 2009). Therefore, evaluation of the microbial quality of water is an important weapon to the achievement of potable water for daily consumption. This study seeks to assess the bacteriological quality of ground water at the Agbowo community via the use of microbial counts (Total aerobic plate and Total coliform) to determine the microbial quality of the ground water and the relationship between the distances of the wells to septic tanks.

\section{MATERIALS AND METHODS}

\section{Study area}

Samples were collected from the Agbowo community in the Ibadan North Local Government Area of Oyo state, Nigeria. Agbowo which is located on latitude $7^{\circ} 26^{\prime} 39^{\prime \prime} \mathrm{N}$ and longitude $3^{\circ} 54^{\prime} 57^{\prime \prime} \mathrm{E}$ is one of the largest communities in Ibadan North. Ibadan north has a population of 306,795 , (NBS, 2006) making it densely populated and having the highest residents in the state. The community is largely occupied by students and staff of the University of Ibadan and The Polytechnic Ibadan as well as other local occupants.

\section{Sample collection}

Forty (40) ground water samples with replicates were collected from wells for bacteriological analysis. The samples were collected at random from Agbowo area a representative of the whole number of wells present. Samples were collected aseptically into sterile $10 \mathrm{~mL}$ bijou bottles that were fitted with screw caps and properly labeled. Two samples each were collected from each well after which they were transported to the laboratory on ice in order to maintain the microbial population and processed for microbial presence that same day. The wells and septic tanks locations were determined using the eTrex GPS device. A tape rule was used in measuring the distances between the septic tanks and wells.

\section{Laboratory investigation}

\section{Preparation of media and total viable counts}

All the media used in this study were prepared and sterilized according to manufacturer's instructions. The media used included; MacConkey agar (Biotec, UK)for Total coliform counts and Plate count agar (Biotec, UK) for Total aerobic plate count. The samples were serially diluted to $10^{-8}$. Using the Standard plate method, $0.1 \mathrm{~mL}$ was inoculated using a glass spreader and incubated at $37^{\circ} \mathrm{C}$ for $18-24 \mathrm{~h}$. For the Total coliform count a 0.1 dilution level was used and only lactose fermenters (pink colonies) were counted. The number of distinct colonies on the plates was enumerated using a digital colony 
counter (Lapiz $^{\circledR}$, Mumbai, India). Total coliform and aerobic counts was estimated and recorded in colony forming units per $\mathrm{mL}$ (CFU/mL). Mean log $\mathrm{CFU} / \mathrm{mL}$ of replicates for the counts were determined (Roe and Cardinale, 2005).

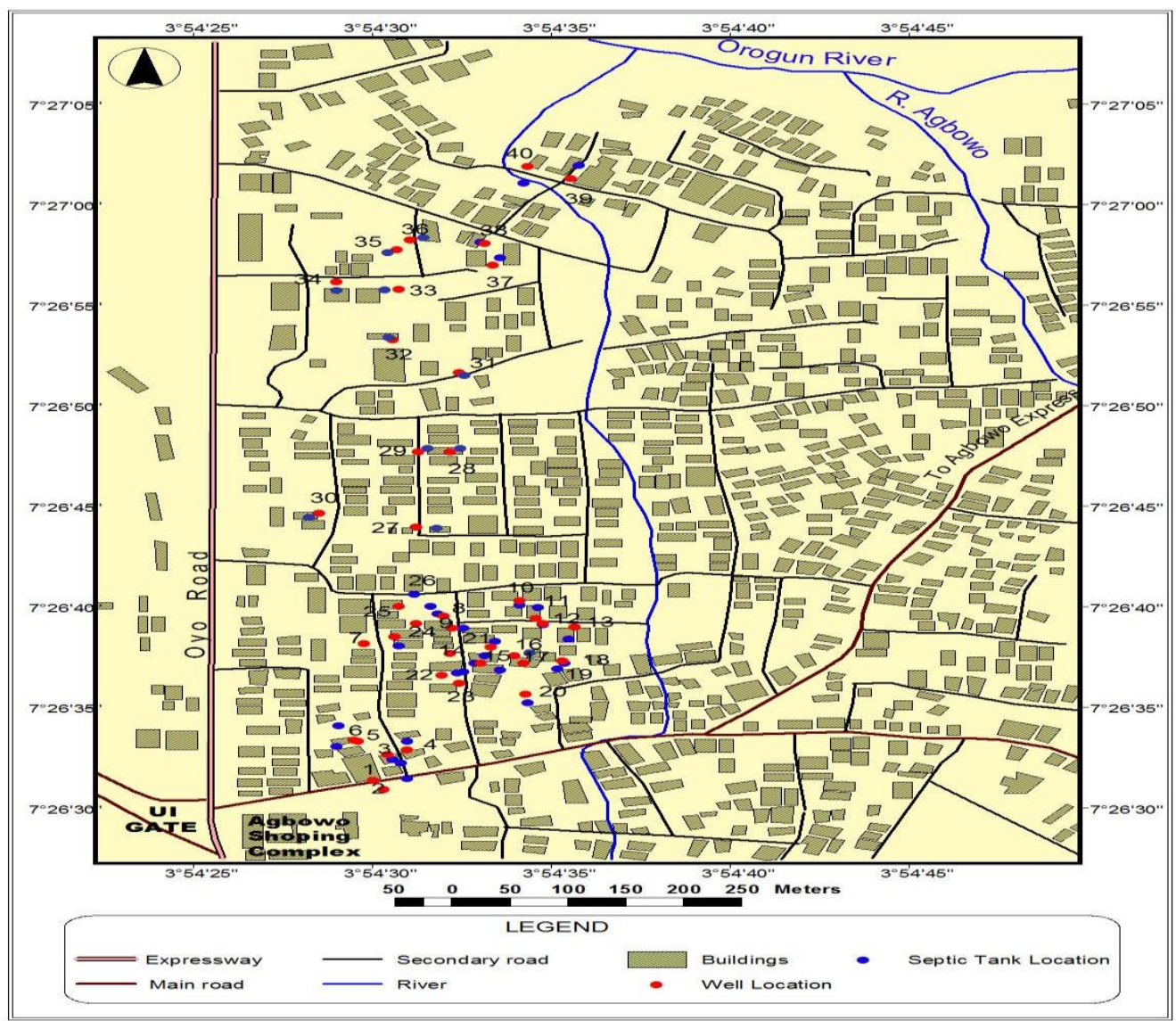

Source: Centre for Remote Sensing and Cartography, Department of Geography, University of Ibadan, Nigeria, 2010.

Figure 1: Map of study area showing well and septic tank locations.

\section{Analysis of data}

In view of the high microbial counts, the wells sampled were classified into different 7 (seven) groups describing the factors that could be responsible for contamination of the ground water and two groups describing whether the well was covered or not covered. One-way ANOVA was used to compare the seven groups while the T-test was used to compare the covered and the uncovered wells. A correlation analysis was also carried out to establish the degree of relationship between the counts and the distances between the septic tanks and wells.

\section{RESULTS}

It was observed that all the water samples collected were contaminated with coliforms and other bacteria. The mean microbial counts obtained were high ranging from 2.83 to $7.09 \log \mathrm{CFU} / \mathrm{mL}$ for total aerobic count and from $<1.00$ to
$3.58 \log \mathrm{CFU} / \mathrm{mL}$ for Total coliform count. The distance of the wells to the septic tanks averages $8.93 \pm 3.61 \mathrm{~m}$. In virtually all the wells sampled, the Total aerobic plate counts were higher than the Total coliform counts.

Table 1 gives the mean values of Total Aerobic Plate and Total Colifrom counts of different well types and their distances to septic tanks. There was a weak negative correlation $\left(r^{2}=-0.180\right)$ which is not significant at $p<0.05$ between the distances from septic tanks and the Total Aerobic Plate Counts though a very weak positive correlation $\left(r^{2}=0.021\right)$ ensued between the distance from septic tanks and Total coliform counts which was significant at $p<0.05$. Also, a weak negative correlation $\left(r^{2}=-0.261\right)$ not significant at $p<0.05$ was seen between the Total coliform and the Total aerobic plate counts. Mean Total aerobic plate count (10.79 $\pm 1.12 \log \mathrm{CFU} / \mathrm{mL})$ was highest for wells that were covered and were located in dirty environment. It was lowest in wells that were covered with metal locks (3.78 $\pm 1.08 \log \mathrm{CFU} / \mathrm{mL})$. 
However, wells with metal locks had the highest Total coliform counts $(2.64 \pm 0.69 \log C F U / \mathrm{mL})$ while the least (1.01 log CFU/mL) was observed in a single well located in a house with a high number of inhabitants. Distance between wells and septic tanks was highest in wells $(12.9 \pm 4.16 \mathrm{~m})$ in which both the drawer and pumping machine were used in getting access to the well water and lowest $(7.44 \pm 2.64 \mathrm{~m})$ in covered wells with metal locks. All results obtained were above the international standards.

No statistical significant difference at $p<0.05$ between the average distance of the wells from septic tank and the microbial counts (Total aerobic plate and Total coliform counts) was observed for the covered and uncovered wells (Table 2).

Table 1: Mean values of Total Aerobic Plate and Total Coliform counts of well types and their distances to septic tanks

\begin{tabular}{llllll}
\hline Type of well & $\begin{array}{l}\text { Distance from } \\
\text { septic tank } \\
(\mathrm{m})\end{array}$ & $\begin{array}{l}\text { Distance } \\
\text { from septic tank } \\
(\mathrm{m})(\mathrm{USEPA} \\
\text { Standard })\end{array}$ & $\begin{array}{l}\text { Total Aerobic } \\
\text { Plate count }(\text { log } \\
\text { CFU/mL) }\end{array}$ & $\begin{array}{l}\text { Total Coliform } \\
(\text { log CFU/mL) }\end{array}$ & $\begin{array}{l}\text { WHO/USEPA } \\
\text { Standard for } \\
\text { the counts } \\
(/ \mathrm{mL})\end{array}$ \\
\hline $\begin{array}{l}\text { Covered + } \\
\begin{array}{l}\text { Pumping } \\
\text { machine + drawer }\end{array}\end{array}$ & $12.9 \pm 4.16$ & 15.24 & $4.77 \pm 0.11$ & $1.93 \pm 0.62$ & 0.0 \\
$\begin{array}{l}\text { Covered + drawer } \\
\text { Covered + metal }\end{array}$ & $10.06 \pm 4.16$ & 15.24 & & & 0.0 \\
$\begin{array}{l}\text { lock } \\
\text { Covered + dense } \\
\text { population }\end{array}$ & $10.44 \pm 2.64$ & 15.24 & $4.04 \pm 0.85$ & $2.54 \pm 0.19$ & 0.0 \\
$\begin{array}{l}\text { Covered + clean } \\
\text { environment }\end{array}$ & $10.21 \pm 3.59$ & 15.24 & $3.78 \pm 1.08$ & $2.64 \pm 0.69$ & 0.0 \\
$\begin{array}{l}\text { Not covered + dirty } \\
\text { environment }\end{array}$ & $7.92 \pm 3.54$ & 15.24 & $6.47 \pm 0.00$ & $1.01 \pm 0.00$ & 0.0 \\
$\begin{array}{l}\text { Covered + dirty } \\
\text { environment }\end{array}$ & $10.79 \pm 1.12$ & 15.24 & $5.15 \pm 0.65$ & $1.79 \pm 0.56$ & 0.0 \\
\begin{tabular}{l} 
Total \\
\hline
\end{tabular} & $8.93 \pm 3.61$ & 15.24 & $5.26 \pm 1.70$ & $2.30 \pm 0.68$ & 0.0 \\
\hline
\end{tabular}

Table 2: Mean values of Total Aerobic Plate and Total Colifrom counts of covered and uncovered wells and their distances to septic tanks

\begin{tabular}{llllll}
\hline Type of well & $\begin{array}{l}\text { Distance from } \\
\text { septic tank }\end{array}$ & $\begin{array}{l}\text { Distance } \\
\text { from septic tank } \\
(\mathrm{m}) \text { (USEPA }\end{array}$ & $\begin{array}{l}\text { Mean Total } \\
\text { aerobic } \\
\text { count } \pm \text { standard } \\
\text { Standard) }\end{array}$ & $\begin{array}{l}\text { Mean Total } \\
\text { coliform } \\
\text { count } \pm \text { standard }\end{array}$ & $\begin{array}{l}\text { WHO/USEPA } \\
\text { Standard for the } \\
\text { counts }(/ \mathrm{mL})\end{array}$ \\
\hline Covered & $9.099 \pm 0.634$ & 15.24 & $4.847 \pm 0.232$ & $2.312 \pm 0.119$ & 0.0 \\
Uncovered & $7.802 \pm 1.585$ & 15.24 & $4.177 \pm 0.751$ & $2.195 \pm 0.208$ & 0.0 \\
\hline
\end{tabular}

\section{DISCUSSION}

The results of bacteriological analysis of well water from the Agbowo community showed that all the wells were contaminated with coliform sand other bacteria. Mean total aerobic plate and Total coliform counts were high with the Total aerobic plate counts being higher. These high counts might have arisen due to the poor level of hygiene and sanitation observed in this community. Wells in this area are constantly exposed to contamination from human activities. Also, the layout of the houses is not well planned such that the distances between wells and septic tanks and even refuse dumps are very minimal. Adekunle, (2008), Fasunwon et al. (2008), Oparaocha et al. (2008) and Adelekan, (2010) have also reported higher heterotrophic bacterial counts too. In some studies conducted in the country, Ifabiyi (2008) and Akinbile and Yusoff (2011), recorded high values for Total coliform counts in various groundwater wells. Others noted high
Total aerobic counts (Shittu et al., 2008; Akahaan et al., 2010; Orebiyi et al., 2010; Adejuwon and Mbuk, 2011). These are in a sharp contrast with WHO (2008) and USEPA (2009) standards that stated that total coliform bacteria must not be detectable in any $100 \mathrm{~mL}$ of water meant for drinking or for treated water entering distribution systems. These high parameters are of great concern to public health since the water from these wells is consumed by people without treatment (Adekunle et al., 2007). The presence of coliform in water is an indication of feacal contamination and has been associated with waterborne epidemic (Mackenzie et al., 1995). Any water source used for drinking or cleaning purposes should not contain any organism of fecal origin (Akeredolu, 1991).

The analysis of the relationship between bacterial indicator levels and environmental characteristics presents several statistical challenges (Bai and Lung, 2006). The negative correlation obtained between the Total aerobic plate count and the distances to septic tanks 
connoted that the total bacteria load in the groundwater wells would decrease with distance. Several other factors apart from the distances of the wells to septic tanks promoted the bacterial contamination of the wells as

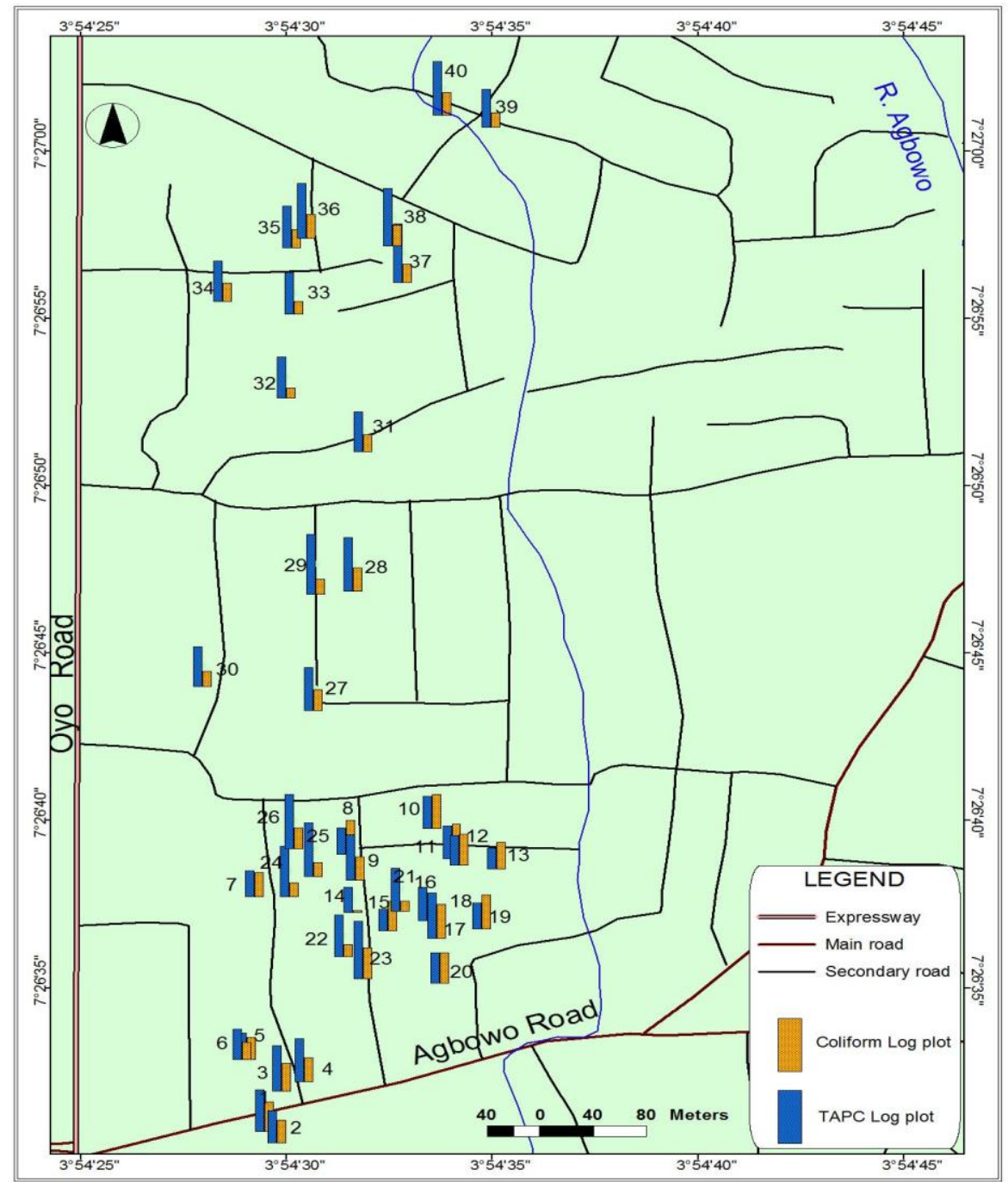

Source: Centre for Remote Sensing and Cartography, Department of Geography, University of Ibadan, Nigeria, 2010.

Figure 2: Map of study area showing Total aerobic plate and Total coliform counts for the well locations.

deduced from the weak positive correlation that ensued between the total coliform count and the distances. A strong relationship between two indicators may provide some evidence that both indicators originate from the same or similar contamination sources (Francy et al., 2000). Due to the complex nature of fecal coliform destination and transport, empirical methods such as regression models are unable to build up reliable loadconcentration relationships (Bai and Lung, 2006).

The covered wells in dirty environment, covered wells in a dense populated house and uncovered wells in dirty environment that demonstrated high Total aerobic plate counts, might have possibly originated from majorly environmental factors. Covering a well without maintaining a good level of environmental hygiene will lead to contamination of groundwater. Also, if the number of people accessing a particular well, there is a high degree of it being contaminated. In a field survey reported by Ojeifo (2011), only about $18.7 \%$ of local residents in a part of the country clean their wells once every year. Dirty environments easily breed microorganisms. This is in agreement with the fact that coliform bacteria are widely found in nature (Binnie et al., 2002; Griffiths et al., 2003). Poor town planning, dilapidated infrastructure and indiscriminate sitting of wells and boreholes contributed to the low bacteriological quality of domestic water supplies, while Rainfall accentuated the impact (Egwari and Aboaba, 2002). Microbiological contamination is 
dispersed, sporadic, and influenced by a range of interacting environmental factors such as the watershed's physical characteristics, climatic conditions, and management practices (Valenzuela et al., 2009). Though covered wells with metal locks had low mean total aerobic plate counts $(3.78 \pm 1.08 \log \mathrm{CFU} / \mathrm{mL})$.

This is possibly as a result of the protection in form of the locks provided for the wells and it equally signified that there is level of restricted access to such wells. Valenzuela et al. (2009) suggested that the most important factors affecting well vulnerability to bacterial contamination were those related to the well itself: construction and site management while it usage and maintenance are also crucial. However, concentrations of microbiological contamination indicator organisms observed in groundwater are a function of the contamination sources active at that moment (SoloGabriele et al., 2000). These further explain why no significant difference was observed between the covered and uncovered wells.

The distances of the wells form septic tanks recorded in this study averages $8.93 \pm 3.61 \mathrm{~m}$. At this distance, total aerobic plate and coliform counts averages $4.76 \pm 1.41 \mathrm{log}$ $\mathrm{CFU} / \mathrm{mL}$ and $2.29 \pm 0.67 \mathrm{log} \mathrm{CFU} / \mathrm{mL}$ which contradict the USEPA/WHO standards. The minimum standard distance set by the USEPA/US- HUD/FHA, Canadian, and UK governments is $15.24 \mathrm{~m}$ (50 ft) (InspectAPedia, 2010). Leachate from septic systems has been identified as a major potential source of groundwater contamination from pathogens such as bacteria, viruses, helminths, and protozoa, nutrients (nitrogen, phosphorus) etc Gerba and James, 2005; Fong et al., 2007; Horn and Harter, 2011).

Coliforms could travel through a distance of 70.7 $\mathrm{m} \quad(232 \mathrm{ft})$ from sewage trenches intersecting groundwater, while traveling through Sand and pea gravel aquifer in $35 \mathrm{~h}$ will cover $30.5 \mathrm{~m}$ (100 ft) from Primary sewage injected subsurface (Crane and Moore, 1984). Presence of septic systems and well depth were found to be related to detection of coliforms in groundwater, although these relationships were not statistically significant (Francy et al., 2000). Effect of distance from pollution sources was more pronounced on fecal and total coliform counts, which decreased with increasing distance from waste dumps and defecation sites (Adekunle et al., 2007). Chiroma et al. (2007) also recorded high bacterial counts in well at $3 \mathrm{~m}$ from drainage effluent and well in a residence house at $2 \mathrm{~m}$ from pit latrine and $2 \mathrm{~m}$ from refuse dump. These results were consistent with the findings of Shimizu et al. (1980) whose studies showed that more microbial activities were found in wells close to organic waste sites in Japan. The dense population of the Agbowo community could be a major factor responsible for the high counts observed. Shimizu et al. (1980) have shown that bacteria contaminate well water, depending on location. Shekwolo and Brisbe in 1999 recorded high counts in Minna, a densely populated city in Niger state, Nigeria, as compared to other towns in the state. This is also similar to works published by Musa et al. (1999), Ifabiyi (2008) and Obiri-Danso et al. (2009) where high bacterial counts were recorded from wells in lbadan North
East Local Government, Northern Sudan and Kumasi (Ghana) respectively. Also other factors such as; the environment where the well was sited and the level of hygiene of the well; in terms of the use of drawers and the population of people the well is serving and its surroundings could be considered as other possible sources of contamination aside the septic tanks. Coliform counts in houses having covered wells with drawers were relatively high $(2.54 \pm 0.19 \log \mathrm{CFU} / \mathrm{mL})$. Wells in dirty environments and in house with dense population had very high total aerobic plate counts. A cumulative increase use of the wells over and above the septic tanks/latrines might lead to failure of the septic tank system. This can increase the risk of contaminants entering drinking water sources (Katz et al., 2011). The river that flows through the Agbowo community is a potential source of contamination for the wells. Some houses do not have to toilets or latrines and thereby dispose off defecated materials in the river, thus increasing the level of well contamination. About $10 \%$ of 150 wells sampled in Esan-land, Nigeria were neither threatened by flooding or erosion nor located close latrines and septic tanks (Ojeifo, 2011).

As the importance of safe guarding quality of water supply has become widely recognized, standards regarding septic tank placement should be reviewed if there be any at all. This can be achieved by imposing minimum lot size requirements larger than those which have been found to be associated with ground water contamination. Another is to evaluate each potential site individually taking into consideration the geological characteristics of the site and methods of waste disposal being practiced in the area. A third approach could be to calculate the amount of dilution of effluent that is required before it reaches the ground water to minimize the pollution potential. All this should be considered critically for further studies.

\section{CONCLUSION}

Results of this study are significant because, a large population of people in the area of survey rely on septic tanks and wells. Therefore residents may be at risk of suffering from water borne illnesses after consumption of water without treatment. In addition, the study indicates that present distances between wells and septic tanks coupled with the level of hygiene of these wells are insufficient to prevent ground water contamination. The problem of ground water contamination via septic tank is not an isolated problem of the area surveyed but rather a nationwide problem hence precautions should be taken by setting standards for sitting of wells from septic tanks and treatment of well water before use.

\section{REFERENCES}

Adejuwon J. O. and Mbuk, C. J. (2011). Biological and physiochemical properties of shallow wells in Ikorodu town, Lagos Nigeria Journal of Geology and Mining Research 3(6), 161-168. 
Adekunle, I. M., Adetunji, M. T., Gbadebo, A. M. and Banjoko, O. B. (2007). Assessment of groundwater quality in a typical rural settlement in Southwest Nigeria. International Journal of Environmental Research and Public Health 4(4), 307-318.

Adekunle, A. S. (2008). Impacts of industrial effluent on quality of well water within Asa Dam Industrial Estate, llorin, Nigeria. Nature and Science 6(3), 1-5.

Adelekan, B. A. (2010). Water quality of domestic wells in typical African communities: Case studies from Nigeria. International Journal of Water Resources and Environmental Engineering 2(6): 137-147.

Akaahan, T. J., Oluma, H. O. A. and Sha'Ato, R. (2010). Physico-chemical and Bacteriological Quality of Water from Shallow Wells in Two Rural Communities in Benue State, Nigeria. Pakistan Journal of Analytical and Environmental Chemistry 11(1), 73-78.

Akeredolu, F. A. (1991). Setting water Quality-water Quality Standards for Nigeria. In: Proceedings of Proceedings of First National Conference On Water Quality Monitoring and Status in Nigeria, Kaduna. pp. 216-224.

Akinbile C. O. and Yusoff, M. S. (2011). Environmental impact of leachate pollution on groundwater supplies in Akure, Nigeria. International Journal of Environmental Science and Development 2(1), 81-86.

Alonge, D. O. (2005). Textbook of meat and milk hygiene. Farmcoe press, Ibadan. pp. 32.

Bai S. and Lung, W. S. (2006). Three-dimensional modeling of fecal coliform in the tidal basin and Washington channel, Washington, DC. Journal of Environmental Science and Health. Part A, Toxic/Hazardous Substances and Environmental Engineering. 41, 1327-1346.

Bell, B. P., Goldoft, M., Griffin, P. M. and Davis, M. A. (1994). A multistate outbreak of Escherichia coli 0157:H7-associated bloody diarrhea and heamolytic uremic syndrome from hamburgers. The Washington experience. JAMA 272(17), 389-408.

Binnie, C., Kimber, M. and Smethrust, G. (2002). Basic water treatment. Royal Society of Chemistry, Cambridge, UK.

Bourne, A. C. (2001). Assessing the contamination $r$ isk of private well water supplies in Virginia. A MSc (Biological Systems Engineering) Thesis submitted to the faculty of the Virginia Polytechnic Institute and State University, USA.

Bridgman, S. A., Robertson, R. M., Syed, Q. and Speed, N. (1995). Outbreak of cryptosporidiosis associated with a disinfected ground water supply. Epidemiology Infection 115(3), 555-566.

CDC (1993). Assessment of inadequately filtered public drinking water -Washington, D. C

Chiroma, T. M., Ugheoke, B. I. and Patrick, D. O. (2007). Environmental impact on the quality of water from hand-dug wells in Yola Environs. Academic Direct 10, 67-76.

Conboy, M. J. and Goss, M. J. (2000). Natural protection of groundwater against bacteria of fecal origin. Journal of Contaminant Hydrology 43(1), 1-24.
Crane, S. R. and Moore, J. A. (1984). Bacterial pollution of groundwater: A review. Water, Air, and Soil Pollution 22, 67-83.

Egwari, L. and Aboaba, O. O. (2002). Environmental impact on the bacteriological quality of domestic water supplies in Lagos, Nigeria. Revista de Saúde Pública 36(4), 513-520.

Fasunwon, O., Olowofela, J., Akinyemi, O., Fasunwon, B. and Akintokun, O. (2008). Contaminants evaluation as water quality indicator in Ago-Iwoye, South-western, Nigeria. African Physical Review 2:0012.

Fenwick, A. (2006). Waterborne infectious diseaseCould they be consigned to History? Science 313, 1077-1061.

Fong, T. T., Mansfield, L. S., Wilson, D. L., Schwab, D. J., Molloy, S. L. and Rose, J. B. (2007). Massive microbiological groundwater contamination associated with a waterborne outbreak in Lake Erie, South Bass Island, Ohio. Environmental Health Perspectives 115, 856-863.

Francy, D. S., Helsel, D. R. and Nally, R. A. (2000). Occurrence and distribution of microbiological indicators in groundwater and stream water. Water Environment Research 72, 152-161.

Gerba, C. P., Rose, J. B. and Hass, C. N. (1996). A sensitive population: Who is at risk? International Journal of Food Microbiology 30, 113-123.

Gerba C., James, E. (2005). Sources of pathogenic microorganisms and their fate during land application of wastes. Journal of Environmental Quality 34, 4248.

Griffin, P. M. and Tauxe, R. V. (1991). The epidemiology of infections caused by Escherichia coli 0157:H7, other enterohemorrhagic E. coli, and the associated hemolytic uremic syndrome. Epidemiologic Reviews 13, 60-98.

Griffiths, J. F., Welsberg, B. S. and McGee, D. C. (2003). Evaluation of microbial source tracking methods using mixed feacal sources in aqueous test samples. Journal of Water and Health 1, 141-151.

Ifabiyi, I. P. (2008). Depth of hand dug wells and water chemistry: Example from Ibadan Northeast Local Government Area (L.G.A.), Oyo-state, Nigeria. Journal of Social Sciences 17(3), 261-266.

InspectAPedia (2010). Online table of required well clearances: Distances between drinking water wells and septic systems, treated soils, farm buildings \& other site features. Retrieved from www. InspectAPedia.com/water/ClearancesWells.htm [accessed on 4th May, 2010].

Isikwue, M. O., lorver, D. and Onoja, S. B. (2011). Effect of depth on microbial pollution of shallow wells in Makurdi Metropoilis, Benue State, Nigeria. British Journal of Environment and Climate Change 1(3), 6673.

Katz, B. G., Eberts, S. M. and Kauffman, L. J. (2011). Using $\mathrm{Cl} / \mathrm{Br}$ ratios and other indicators to assess potential impacts on groundwater quality from septic systems: A review and examples from principal 
aquifers in the United States. Journal of Hydrology 397,151-166.

Lin, C. Y., Abdullah, M. H., Musta, B., Aris, A. Z., and Praveena, S. M. (2010). Assessment of selected chemical and microbial parameters in groundwater of Pulau Tiga, Sabah, Malaysia. Sains Malaysian 39(3), 337-345.

Longe, E. O. and Balogun, M. R. (2010). Groundwater quality assessment near a Municipal Landfill, Lagos, Nigeria. Research Journal of Applied Sciences Engeering and Technology 2(1), 39-44.

Mackenzie, W. R., Schell, W. L., Blair, K. A. and Addiss, D. G. (1995). Massive outbreak of waterborne cryptosporidium infection in Milwaukee, Wiscousin: recurrence of illness and risk of secondary transmission. Clinical Infectious Diseases 1, 57-62.

Mintz, E., Bartram, J., Lochery, P. and Wegelin M. (2001). Not just a drop in the bucket: Expanding access to point of use water treatment systems. American Journal of Public Health 91, 1565-1570.

Musa, H. A., Shears, P., Kafi, S. and Elsabag, S. K. (1999). Water quality and public health in northern Sudan: a study of rural and peri-urban communities. Journal of Applied Microbiology 87, 676-682.

NRC (1998). Issues in potable reuse, $1^{\text {st }}$ ed. National Academy press, Washington, D. C.

Obi, O. L., Polgieter, N., Bessong, P. O. and Matsung, G. (2002). Assessment of the microbial quality of river water sources in rural Venda communities in South African. Water South Africa 26, 287-292.

Obiri-Danso, K., Adjei, B., Stanley, K. N. and Jones, K. (2009). Microbiological quality and metal levels in wells and boreholes water in some peri-urban communities in Kumasi, Ghana. African Journal of Environmental Science and Technology 3(1), 059066.

Ojeifo, O. M. (2011). Assessment of rain water harvesting facilities in Esanland of Edo State, Nigeria. Journal of Human Ecology 34(1), 7-16.

Onunkwo A. and Uzoije, A. P. (2011). Exploratory survey of geochemical aspects of underground water in Ehime Mbano Area Se Nigeria. Global Journal of Research in Engineering 11, 14-22.

Oparaocha, E. T., Iroegbu, O. C. and Obi, R. K. (2008). Assessment of quality of drinking water sources in the Federal University of Technology, Owerri, Imo state, Nigeria. Journal of Applied Biosciences 32, 19641976.

Orebiyi, E. O., Awomeso, J. A., Idowu, O. A., Martins, O., Oguntoke, O. and Taiwo, A. M. (2010). Assessment of pollution hazards of shallow well water in Abeokuta and Environs, Southwest, Nigeria. American Journal of Environmental Sciences 6(1), 50-56.

Roe, D., Cardinale, J. A. (2005). Evaluation of microbial structures and persistence in the Alfrad wastewater treatment plant. Reed Bed Sludge Treatment System.
Scott, T. M., Rose, J. B., Jenkins, T. M., Farrah, S. R. and Lukasik, J. (2002). Microbial source tracking: Current methodology and future directions. Applied Environmental Microbiology 68, 5796-5803.

Shekwolo, P. D. and Brisbe, M. O. (1999). Bacteriological properties of groundwater in parts of Niger state, Nigeria. Journal of Environmental Hydrology 17, Paper 12.

Shimizu, T. T. M., Kigotake, T. M. and Agatomo, H. N. (1980). Bacteria contamination of drinking water from wells in Miyazaki, Japan. In: Bulletin for Agriculture. Miyakazi University. pp. 21-28.

Shittu, O. B., Olaitan, J. O. and Amusa, T. S. (2008). Physico-chemical and bacteriological analyses of water used for drinking and swimming purposes in Abeokuta, Nigeria. African Journal of Biomedical Research 11, 285- 290.

Simango, C., Dinolwe, J. and Rukure, G. (1992). Bacterial contamination of food and household stored drinking water in a farm working community in Zimbabwe. Central Africa Journal of Medicine 36, 143-148.

Simpson, J. M., Sarto Domingo, J. W. and Reasoner, D. J. (2002). Microbial source tracking: state of science. Environmental Science and Technology 36, 527-528.

Solo-Gabriele, H. M., Wolfert, M. A., Desmarais, T. R. and Palmer, C. J. (2000). Sources of Escherichia coli in a coastal subtropical environment. Applied Environmental Microbiology 66, 230-237.

Swerdlow, D. L., Woodruff, B. A. and Brady, R. C. (1992). A waterborne outbreak in Missouri of Escherichia coli 0157:H7 associated with bloody diarrhea and death. Annals of Internal Medicine 117(10), 812- 819.

USEPA (1977). The report to Congress-Waste Disposal Practices and their effects on ground water. U. S. Environmental Protection Agency, Washington, D.C.

USEPA (2009). National Primary Drinking Water Regulations. EPA 816-F-09-004. Washington, D.C.

Valenzuela, M., Lagos, B., Claret, M., Mondaca, M. A., Pérez, C. and Parra, O. (2009). Fecal contamination of groundwater in a small rural dryland watershed in central Chile. Chilean Journal of Agricultural Research 69(2),235-243.

WHO (2008). Guidelines for drinking-water quality, third edition, incorporating the first and second addenda volume 1, Recommendations. WHO, Geneva.

Yusuf, K. A. (2007). Evaluation of groundwater quality characterisitics in Lagos-City. Journal of Applied Sciences 7(13), 1780-1784. 